the following day, but how could such a regulation be observed in polar regions where the sun neither rises nor sets for months? These and other arguments show conclusively that the Sabbath is not absolute, but a function of physical and political geography. In addition, there are many precedents in Jowish history for the concept of the year undergoing changes, as, for example, making the month of Tishri the first month of the calendar year instead of Nisan, in flagrant defiance of the command mentioned in Exodus xii, 2. Except for a small body of Christian Sabbatarians, Judaism seems to be the only opponent of the reformed calendar on religious grounds, and if world opinion should show a substantial majority in favour of reform, it would be unreasonable to post. pore the change in deference to the wishes of a race that represents only about $0 \cdot 5 \mathrm{per}$ cent of the world's population.

\section{Directory of International Scientific Organizations}

IN accordance with a decision of the General Conference of the United Nations Fducational, Scientific and Cultural Organization in November-December 1952, the second edition of the Organization's "Directory of International Scientific Organizations" (pp. 312. Paris: Unesco ; London: H.M.S.O., 1953. 2.50 dollars, $13 s .6 d$. or 650 franes) has been published only in English, the language which commanded the larger sales of the first edition. It is arranged on similar lines to the first edition, and although certain bodies included in the first edition are now omitted in the absence of up-to-date information and other defunct ones are no longer listed, 264 organizations, as against 202 in the first edition, are described, though a few of those given in the "Miscellaneous" section appear to have somewhat slender claims to be regarded as scientific organizations in the usual sense of the term. As previously noted, the contents pages, with their interpretation of the initials and symbols so commonly inflicted on the reader in place of names and titles, and the adequate subject index make the volume a most useful reference work to men of science generally as well as to the librarian.

\section{New Education Scheme of the Institute of Fuel}

IN the July issue of the Journal of the Institute of Fuel is an informative account of the new education scheme of the Institute of Fuel, contributed by the chairman of the Institute's Education Committee, Dr. D. T. A. Townend. Among the activities of such a professional body, the devolopment of its educational aims must always be a matter of prime importance; for to a chartered body the professional competence and corresponding status of its members must be factors in which the highest standards must progressively be assured. One needs to recall the background against which the first education scheme was framed following the report of the Sibly Committee made more than a decade ago. That Committee, set up by the Advisory Council of the Department of Scientific and Industrial Research to inquire into the supply of trained fuel technologists, reviewed both the urgent short-term and the longterm problems involved; the educational activities of the Institute had in some measure contributed towards the progress envisaged. Some weaknesses in the early scheme were revealed by practical experience of its working, and these have been remedied in the new scheme now coming into operation. A professional body must always gather much of its strength from members educated in the universities and technological institutions. There are, however, in these days of part-time release from industry for further education, a large number of potential technologists, much needed in industry. The now scheme is particularly directed towards their welfare if their livelihood is concerned with the many-sided aspects of fuel technology. A grouped course of study is prescribed in which five years is intended to be occupied on part-time study of the scientific background and the technological essentials. For those who are fortunate enough to be able to profit by full-time educational facilities, a valuable detailed account is given of the resources of Britain in a collective statement which has not previously been made available to the intending student. The discussion of the scheme by the members of the Institute is apponded to the paper.

\section{Brotherton Library and Collection of the University} of Leeds

THE annual report of the Librarian, University of Leeds, for the session 1952-53 (pp. 12; from the University), records holdings of 365,912 volumes and 159,090 pamphlets at June 30,1953 , of which 266,053 volumes and 109,171 pamphlets are in the Brotherton Library. Special reference is made to the use of aluminium and plastic in the new mezzanine floor of the Brotherton Library in which radiating lines of bookcases converge on the centre of a circle $104 \mathrm{ft}$. in diameter, and the new floor and shelving are supported at basement-level by aluminium stanchions spaced at, a uniform distance of $3 \mathrm{ft} .6 \mathrm{in}$. Horizontal supporting members are fixed at the top of the stanchions, which in turn support parallel beams, between which are inserted standard 'Holoplast' sheets. Each stanchion accommodates four perforated steel channels, the centres of the porforations being $1_{4}^{1}$ in. apart, and this is the only use of steel in an otherwise entirely aluminium structure which is believed to mark a new departure in library planning. The new floor is covered with a cork linoleum specially treated to preserve its sound. absorbent quality.

The eighteenth annual report of the Brotherton Collection Committeo of the University (pp. 10; University of Leeds, 1954) covers the session 1952-53, during which three main exhibitions were arranged. The first of these related to the Poets Laureate of England, the second to three Queens of EnglandElizabeth I, Anne and Victoria-and the third was an exhibition of items from the collection of atlases, maps and road-books presented to the University by the late Dr. Harold Whitaker. The Collection was also open, usually with special exhibitions, to learned societies whieh were guests of the University; these included the Thirteenth British Congress of Gynecologists and Obstetricians (July 1952), the Royal Astronomical Society (July 1952) and the British Association of Urological Surgeons (June 1953). Dr. E. E. Willoughby gave a series of four lectures on "The Uses of Bibliography to the Student of Literature and History" in the Brotherton Room during November. The contents of the Collection on June 30, 1953 , were estimated at 24,220 books; 16,287 pamphlets ; 608 manuscripts ; 4,106 deeds ; 32,269 letters; and 25 maps.

Fitzwilliam Museum, Cambridge : Report for 1953

THE restrictions on new museum buildings are so severe in Great Britain at the present time that it is pleasing to note in the annual report for 1953 of the 